\title{
КОМУНІКАТИВНА СПРЯМОВАНІСТЬ У НАВЧАННІ МОРФОЛОГІЇ В ОСНОВНІЙ ШКОЛІ
}

Цоуфал Л. С. Комунікативна спрямованість у навчанні морфології в основній школі.

У статті розглянуто проблему комунікативної спрямованості в навчанні української мови, окреслено основні шляхи реалізації мети мовної освіти в сучасних умовах середньої школи, запропоновано зразки вправ, спрямованих на формування комунікативних умінь і навичок учнів під час навчання морфології.

Ключові слова: комунікативна спрямованість, комунікативні вміння і навички, комунікативно-діяльнісний підхід, навчання морфології.

Цоуфал Л. С. Коммуникативная направленность в обучении морфологии в основной школе.

В статье рассматривается проблема коммуникативной направленности в обучении украинского языка, выделяются основне пути реализации цели языкового образования в

(ㄱ Л. С. Цоуфал, 2013. 
современных условиях средней школы, приводяться примеры упражнений, направленных на формирование коммуникативных умений и навыков при изучении морфологии.

Ключевые слова: коммуникативная направленность, коммуникативные умения и навыки, коммуникативно-деятельностный подход, обучение морфологии.

Tsoufal L. S. Communicative orientation in the study of the morphology of the basic school.

The paper considers the problem of communicative orientation in the Ukrainian language teaching, outlines the main ways of achieving the goals of language education in today's basic school conditions, gives the examples of the exercises, aimed at students' communicative skills building whilst studying morphology.

Key words: communicative orientation, communicative skills and abilities, communicative approach, morphology learning.

Сучасні підходи в навчанні рідної мови визначаються тими функціями, які нині вона виконує в суспільстві. Розроблення нової стратегії освіти передбачає компетентнісно зорієнтоване навчання, спрямоване на формування в учнів якостей, необхідних людині в будьякій сфері діяльності, у будь-якій життєвій ситуації. Одним із завдань реформування змісту мовної підготовки $\epsilon$ вироблення на основі державних стандартів системи знань про мову й мовлення, мовних i мовленнєвих умінь та навичок, досвіду творчої діяльності й емоційноціннісного ставлення до світу, переорієнтація процесу навчання на розвиток особистості учня, формування системи його компетентностей.

У сучасній лінгводидактиці обстоюється думка, згідно 3 якою показником високого рівня мовної освіти, крім орфографічнопунктуаційної грамотності, є вміння спілкуватися, використовуючи відповідно до потреб комунікації фонетичне, лексичне багатство, різноманітні синтаксичні конструкції, стилістичні можливості рідної мови. Тому одним із головних завдань навчання мови є формування у школярів умінь і навичок комунікативно виправдано користуватися засобами рідної мови в різних життєвих ситуаціях під час сприймання, відтворення i створення висловлювань 3 дотриманням українського мовленнєвого етикету.

Практична спрямованість навчання мови, що «передбачає не лише кількісні переваги практики над лінгвістичною теорією, а насамперед навчання діяльності спілкування» [6, с. 71] стала предметом досліджень багатьох сучасних науковців (3. Бакум, О. Біляєв, М. Вашуленко, О. Глазова, О. Горошкіна, Т. Доченко, С. Срмоленко, С. Караман, А. Ляшкевич, Л. Мамчур, В. Мельничайко, А. Нікітіна, С. Омельчук, М. Пентилюк, К. Плиско, Г. Шелехова). Дослідники намагаються 3'ясувати лінгводидактичні засади навчання мови на комунікативній основі, особливості процесу формування комунікативних умінь і 
навичок учнів на уроках мовленнєвого розвитку та під час засвоєння мовних засобів. Це дає підстави говорити про формування методичної системи комунікативно орієнтованого вивчення української мови.

Основними положеннями комунікативної методики навчання української мови є: 1) лінгвістична наука про мову і мовлення та їх функції у спілкуванні; 2) теорія мовленнєвої діяльності; 3) мовленнєве спілкування та його різновиди; 4) інтерактивне навчання і текстова основа уроків; 5) комунікативна мовленнєва, мовна, соціокультурна й діяльнісна (стратегічна) компетенція учнів [4, с. 16].

Ці положення визначають теоретичний і прагматичний напрями реалізації комунікативної методики в навчально-виховному процесі середньої школи, своєрідність якої полягає в оволодінні школярами всіма формами і видами мовленнєвої діяльності задля спілкування.

Автори Концепції мовної освіти О. Біляєв, М. Вашуленко, В. Плахотник зауважують, що в новій школі не повинно мати місця зайве теоретизування, вербальне заучування граматичних положень i правил. Основний стрижень занять 3 рідної мови - всебічний розвиток усного i писемного мовлення учнів у процесі реалізації комунікативно-діяльнісного підходу [1]. Комунікативно-діяльнісний підхід до навчання мови «полягає в такій організації навчання, коли засвоєння мови відбувається в процесі комунікативної (реальної або змодельованої) діяльності задля оволодіння комунікативними уміннями i навичками; потребує розгляду лінгвістичної теорії як інструмента для практичного оволодіння мовою» [6, с. 71].

Комунікативно-діяльнісний підхід реалізує принцип комунікативності, що спирається на традиції розвитку мовлення. Комунікативна спрямованість характеризується тим, що головною метою навчання визначено формування умінь і навичок мовленнєвого спілкування і шлях до цієї мети - практичне користування мовою. Для формування умінь спілкування необхідно в процесі навчання мови створити умови мовленнєвого спілкування. Система роботи має викликати необхідність спілкування і потребу в ньому. За словами О. Бистрової, «навчатися спілкуванню, спілкуючись, - ось основна характеристика комунікативності» [2, с. 6]. «Оволодіння мовою на комунікативних засадах - не новація; так навчають мови в усьому цивілізованому світі» [7, с. 42]. Науковці підкреслюють, що необхідно не тільки сформувати в учнів уявлення про українську мову, пї правила та закони, домогтися засвоєння норм, а й навчити ефективно використовувати мовні засоби в різних життєвих ситуаціях. М. Степаненко зазначає: «Знання мовних законів - це лише півуспіху. 
Повного успіху можна досягти лише тоді, коли ці закони стануть дійовими, повносило ввіллються в комунікативну практику школяра, коли він вільно й невимушено користуватиметься лексичними і фразеологічними скарбами рідної мови, її потужними словотвірними можливостями, упорядкованою граматичною структурою, коли зможе вилучити зі своєї сфери комунікації суржик, який чіпко обплутав сучасну українську мову, діалектні нашарування, іноді всмоктані 3 молоком матері, коли братиме за взірець вироблені, апробовані впродовж століть норми літературної мови» [7, с. 42].

Аналіз лінгводидактичних джерел дає змогу стверджувати, що комунікативна методика спирається на мовленнєву діяльність мовців $\mathrm{i}$ забезпечує формування комунікативної компетенції мовної особистості.

За визначенням О. Бистрової, комунікативна компетенція - це знання, уміння i навички, необхідні для розуміння чужих i породження власних програм мовленнєвої поведінки, адекватних цілям, сферам, ситуаціям спілкування. Вона передбачає: знання основних понять лінгвістики мовлення - стилі, типи мовлення, побудова опису, розповіді, роздуму, способи зв'язку речень у тексті; уміння i навички аналізу тексту і власне комунікативні уміння уміння і навички мовленнєвого спілкування відповідно до різних сфер і ситуацій спілкування, з урахуванням адресата, стилю [2, с. 5].

М. Вятютнєв розглядає комунікативну компетенцію як вибір і реалізацію програм мовленнєвої поведінки залежно від здатності людини орієнтуватися в тих чи тих умовах спілкування, уміння класифікувати ситуації залежно від теми, задач, комунікативних настанов, що виникають в учнів до бесіди, а також під час бесіди в процесі взаємної адаптації [3, с. 38].

Мовленнєва діяльність $є$ практичною реалізацією соціальних функцій мови, які визначають мету і зміст мовної освіти. Оскільки володіння мовою належить до соціально-культурної інтелектуальної діяльності, у методиці навчання мови, крім основної мети - забезпечення комунікативної компетенції особистості в різних сферах і жанрах мовлення, визначається не менш важлива, яка полягає у формуванні громадянина-патріота на основі засвоєння основних цінностей загальнолюдської і національної культури - матеріальної й духовної.

Лінгводидакти (М. Пентилюк, О. Горошкіна, А. Нікітіна) зауважують, що комунікативна компетенція охоплює не тільки знання мовної системи й володіння мовним матеріалом, а й передбачає дотримання соціальних норм спілкування, правил мовленнєвої поведінки, що становить соціокультурну змістову лінію мовної освіти ○ л. С. Цоуфал, 2013. 
середньої школи. «Комунікативна компетенція - це не вроджена здатність, а сформована на взаємодії мовця із соціальним середовищем у процесі набуття ним соціально-комунікативного досвіду, це знання, уміння і навички, необхідні для розуміння чужих і породження власних програм мовленнєвої поведінки, адекватних цілям, сферам і ситуаціям спілкування» [4, с. 17].

Як переконливо свідчить шкільна практика, формування комунікативних умінь i навичок $є$ актуальною проблемою сучасної методики навчання мови. Часто учні, засвоївши основи науки про мову, відчувають труднощі в мовленнєвому спілкуванні. Невідповідність між теорією і практикою живого спілкування особливо відчувається тоді, коли необхідно застосувати набуті знання для правильного вживання слова, для побудови речень, зв'язних висловлювань 3 певною комунікативною метою. Однак труднощі можуть бути спричинені й індивідуально-особистісними особливостями дитини, 3 урахуванням яких психологи відносять школярів до комунікативного чи некомунікативного типу. Дослідження науковців доводять, що діти першого типу - екстраверти - легко спілкуються, схильні до групових занять, роботи в колективі, із задоволенням беруть участь у рольових іграх, уміють використовувати в процесі навчання мови мовне чуття, прогнозування, а представники некомунікативного типу - інтроверти схильні до аналізу мовного матеріалу, свідомого заучування правил, без бажання долучаються до спілкування, зокрема через побоювання допустити помилку, вони надають перевагу читанню, виконанню письмових завдань, аніж мовленнєвій практиці.

Організовуючи навчальний процес, учитель має дотримуватися певних правил: максимально враховувати індивідуальнопсихологічні, вікові особливості учнів, їх інтереси; створювати на уроці і підтримувати в учнів потребу у спілкуванні; обирати об'єктом навчання мовленнєву діяльність в усіх іï видах і формах (слухання, говоріння, читання, письмо); сприяти засвоєнню комунікативно значущої та цінної для загальнокультурного розвитку інформації; сприяти активізації мисленнєвих резервів i попереднього мовленнєвого досвіду школярів під час виконання завдань; сприяти формуванню комунікативної компетенції.

Реалізація комунікативної спрямованості зумовлює зміну методів, прийомів і засобів навчання. Поряд 3 традиційними великого значення набуває метод моделювання зв'язних висловлювань, який реалізується в різноманітних ситуативних вправах, сконструйованих з урахуванням залежності змісту і мовленнєвого оформлення висловлювань від ситуації 
спілкування. Щоб наблизити умови навчання до природних умов спілкування, необхідно ввести учня в комунікативну ситуацію і навчити його орієнтуватися в ній, тобто ясно уявляти собі співрозмовника, умови мовлення і завдання спілкування.

Комунікативні ситуації створюють для учнів умови, подібні 3 природними: стимулюють їхню уяву, примушують формулювати думки і почуття лінгвістичними засобами, дозволяють будувати комунікативні моделі, граматичні структури, використовувати лексичний арсенал у спілкуванні.

Мета системи комунікативних завдань - формування основних комунікативних умінь: орієнтуватися в умовах спілкування, планувати і створювати власні висловлювання відповідно до ситуації спілкування; добирати мовні засоби, які б відповідали окресленій мовленнєвій ситуації; коригувати висловлювання 3 урахуванням ситуації спілкування, тобто досягнення адекватності мовлення.

Наведемо зразки вправ, які, на нашу думку, доцільно використати під час навчання морфології в основній школі.

1. Уявіть ситуацію: до вас зателефонував однокласник i попросив розказати програму заходів, спланованих на святкування ювілею школи. Складіть висловлювання (4-5 речень). Називаючи час проведення заходів, використовуйте числівники.

2. Уявіть ситуацію: вам дуже потрібна книга, якої не виявилося на поличці у шкільній бібліотеці. Складіть діалог на тему «У бібліотеці» з 6-7 реплік, використайте слова мовленнєвого етикету.

3. Уявіть, що в учителя склалося враження, що домашній твір ти написав (написала) 3 використанням матеріалів з Інтернету. Склади діалог розмови 3 педагогом. Зверни увагу на прислівники, які використано в тексті.

4. Уявіть ситуацію: у ваш клас прийшла нова учениця і вчитель доручила ознайомити іiі із традиціями класу. Запишіть висловлювання. Проаналізуйте, слів якої частини мови використано найбільше.

Створення комунікативних ситуацій на уроці має виняткове значення. Адже такі завдання формують в учнів уміння вільно i творчо використовувати лексичні і граматичні засоби мови, підводять їх до спілкування в умовах природної комунікації, дисциплінують мислення, загострюють чуття мови, привчають гнучко користуватися нею, вибираючи 3 кількох варіантів той, який найбільше підходить для певних умов спілкування.

Отже, для досягнення основної мети мовної освіти в основній школі необхідно реалізувати комунікативну спрямованість у навчанні ○ л. С. Цоуфал, 2013. 
мови, тобто активізувати мовленнєву діяльність школярів, сприяти виробленню комунікативних умінь i навичок, розвивати інтелектуально-розумові якості учнів.

\section{Література}

1. Білясв О. М. Концепція мовної освіти в Україні / О. М. Біляєв, М. С. Вашуленко, В. М. Плахотник // Рідна школа. - 1994. - № 9. - С.71-73.

2. Быстрова Е. А. Коммуникативная методика в преподавании родного языка / Е. А. Быстрова // Русский язык в школе. - 1996. - № 1. - С. 3-8.

3. Вятютнев М. Н. Коммуникативная направненность обучения русскому языку в зарубежных школах / М. Н. Вятютнев // Русский язык за рубежом. - 1977. - №6. C. $38-45$.

4. Пентилюк М. Концептуальні засади комунікативної методики навчання української мови / Марія Пентилюк, Олена Горошкіна, Алла Нікітіна // Українська мова і література в школі. - 2006. - № 1. - С. 15-20.

5. Пентилюк М. Наукові засади комунікативної спрямованості у навчанні рідної мови / Марія Пентилюк // Дивослово. - 1999. - №3. - С. 8-10.

6. Словник-довідник з української лінгводидактики: [навч. посібник] / Кол. авторів за ред. М. Пентилюк. - К. : Ленвіт, 2003. - 149 с.

7. Степаненко М. Реформування освіти і деякі нові підходи до вивчення української мови в школі / М. Степаненко, Н. Степаненко // Дивослово. - 1999. - №9. C. 41-42.

Стаття надійшла до редакції 25.11.2013 p. 